\title{
PERILAKU KEUANGAN IBU RUMAH TANGGA PENGGUNA E-WALLET OVO DI KECAMATAN KEDAWUNG CIREBON
}

\author{
Indri Ferdiani Suarna ${ }^{1}$, Nugraha Nugraha², Maya Sari3 \\ Sekolah Pascasarjana Universitas Pendidikan Indonesia ${ }^{123}$ \\ indribenardi2003@gmail.com¹;nugraha@upi.edu²;mayasari@upi.edu³
}

\begin{abstract}
ABSTRAK
Era digitalisasi dengan perkembangan teknologi dan informasi yang cepat saat ini berdampak pada bidang perekonomian salah satunya dilihat dari sistem transaksi yang mengalami pergeseran alat transaksi tunai menjadi non-tunai atau transaksi uang elektronik. Perilaku pengelolaan keuangan mengacu pada tingkat kemampuan keuangan pengelolaan harian pribadi seseorang mulai dari perencanaan, penganggaran, pemeriksaan, pengeloaan, penyimpanan, pencarian, serta pengendalian. Rendahnya tingkat pengetahuan keuangan di Indonesia masih menjadi salah satu penghambat dalam perkembangan Ewallet diantaranya aplikasi OVO. Pengalaman dalam mengelola keuangan dengan menggunakan OVO pun masih perlu dipertimbangkan. Penelitian ini secara khusus memiliki tujuan untuk mengetahui pengaruh pengetahuan keuangan dan pengalaman keuangan terhadap perilaku keuangan ibu rumah tangga pengguna OVO di kecamatan Kedawung Cirebon. Metode penelitian dengan kuantitatif dan analisis deskriptif. Penelitian ini dilakukan kepada 80 orang responden pengguna OVO dengan menggunakan teknik nonprobability sampling melalui purposive sampling dengan SPSS 24 .Hasil penelitian menyatakan bahwa pengetahuan keuangan berpengaruh secara positif dan signifikan terhadap perilaku keuangan ,pengalaman keuangan berpengaruh secara positif dan signifikan perilaku keuangan, pengetahuan keuangan dan pengalaman keuangan berpengaruh secara bersamaan terhadap perilaku keuangan.
\end{abstract}

Kata Kunci: Pengguna OVO, Ibu Rumah Tangga , Pengetahuan Keuangan,Pengalaman Keuangan Dan Perilaku Keuangan

\section{ABSTRACT}

The era of digitalization with the rapid development of technology and information today, has an impact on the economic sector, one of which is seen from the transaction system that has shifted the instrument of cash transactions to non-cash or electronic money transactions. Financial management behavior refers to the level of financial ability of one's daily management starting from planning, budgeting, checking, managing, storing, searching, and controlling. The low level of financial knowledge in Indonesia is still one of the obstacles in the development of E-wallet, including the OVO application. Experience in managing finances using OVO still needs to be considered. This study specifically aims to determine the effect of financial knowledge, financial experience on the financial behavior of housewives using $O V O$ in the Kedawung Cirebon district. Research method with quantitative and descriptive analysis. This study was conducted on 80 respondents using $\mathrm{OVO}$ using a non-probability sampling technique through purposive sampling with SPSS 24. The results showed that financial knowledge had a positive and significant effect on financial behavior, the financial experience affected financial behavior, financial knowledge, and financial experience had an effect. simultaneously on financial behavior. 
Keywords: OVO users, housewives, financial knowledge, financial experience, and financial behavior

Diterima: 12 September 2021; Direvisi: 29 September 2021; Diterbitkan: Oktober 2021

\section{PENDAHULUAN}

Perkembangan pengguna Fintech dan perusahaan fintech juga terus berkembang dari tahun ke tahun dengan pilihan produk financial technology (fintech) semakin beragam dan salah satunya adalah penggunaan e-wallet. Berdasarkan Peraturan Bank Indonesia No.18/40/PBI/2016, e-wallet adalah sebuah layanan elektronik untuk menyimpan data instrumen pembayaran antara lain alat pembayaran dengan menggunakan kartu dan atau uang elektronik, yang dapat juga menampung dana untuk melakukan pembayaran.(Herlinawati\&Astrie :2021)

Riset The Asian Parent Group menunjukkan, 35\% ibu di Indonesia menggunakan OVO. Mayoritas dari mereka merupakan milenial dan bekerja. Digital payment atau pembayaran secara digital merupakan teknologi yang saat ini berkembang pesat di era industri 4.0 serta merupakan pandangan baru bagi masyarakat dalam melakukan pembayaran non-tunai yang jauh lebih praktis, sistematis dan aman dalam melakukan segala kegiatan transaksi. Sebagian orang mengetahui digital payment adalah uang elektronik yang dapat digunakan dalam melakukan pembayaran dalam berbagai transaksi. Pembayaran dengan e-money akan memberikan kemudahan bagi masyarakat Indonesia dalam melakukan transaksi secara online dengan efektif dan efisien. (Suryani\&umiyati:2020.)

Perkembangan transaksi secara online menunjukan peningkatan secara signifikan dari tahun ke tahun yang dapat mempengaruhi aplikasi mobile payment seperti aplikasi OVO yang merupakan teknologi informasi dalam bidang digital payment.Usman (2017) menyatakan bahwa pembayaran non tunai pembayaran yang dilakukan secara non tunai tidak hanya dengan menggunakan kartu melainkan dengan smartphone.

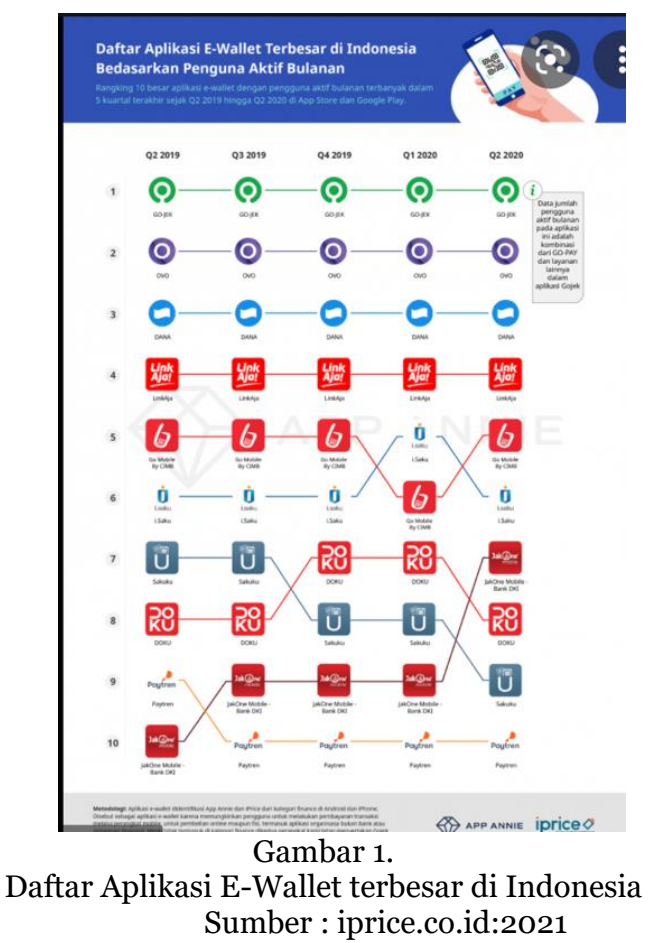

Berdasarkan data tersebut rangking e-wallet di Indonesia juga didominasi oleh pemain lokal. Hal ini bisa dikaitkan dengan suksesnya promosi dan campaign yang dilakukan oleh pengembang e-wallet Indonesia dan dukungan dari pemerintah dalam membawa Indonesia untuk lebih menjadi cashless society. GOPAY, OVO, Dana dan Link Aja merupakan empat ewallet dengan jumlah pengguna aktif 
bulanan terbanyak selama periode Q2 2019- Q2 2020. Untuk aplikasi dengan total download terbanyak juga diduduki oleh keempat pemain tersebut GOPAY, OVO, Dana dan LinkAja.

OVO adalah aplikasi smart yang memberikan Anda kemudahan dalam bertransaksi (OVO Cash) dan juga kesempatan yang lebih besar untuk mengumpulkan poin di banyak tempat (OVO Points). OVO, aplikasi ini mencoba mengakomodasi berbagai kebutuhan terkait dengan cashless dan mobile payment. Aplikasi OVO saat ini tersedia untuk platform Android dan IOS. OVO menggunakan sistem point reward, yang disebut dengan OVO point, untuk menjaga dan meningkatkan transaksi pengguna.Layanan ini terbagi ke dalam dua kategori pengguna, OVO Club (pengguna biasa) dan OVO (Premier. https://www.ovo.id/about). Hasil survei Digital Mum Survey 2020 dan 2021 mengungkapkan sebanyak 35 persen ibu di Indonesia, yang didominasi oleh ibu milenial dan ibu bekerja, mengunduh dan menggunakan OVO sebagai platform pembayaran mereka sehari-hari.

Financial management behavior berhubungan dengan tanggung jawab keuangan seseorang mengenai cara pengelolaan keuangan mereka, (Ida et al., 2010). Saat ini kebutuhan dan keinginan tiap manusia semakin tinggi, sehingga manusia seharusnya memiliki pengetahuan keuangan dan pengalaman dalam mengelola keuangan.

Bhushan \& Medury (2014) menjelaskan literasi keuangan telah menjadi semakin kompleks selama beberapa tahun terakhir dengan pengenalan banyak produk keuangan baru. Minimnya pengetahuan keuangan seseorang dapat menimbulkan masalah keuangan, dimana masalah keuangan bukan hanya fungsi dari rendahnya pendapatan, tetapi juga bisa terjadi karena kesalahan dalam mengelola keuangan, seperti kesalahan dalam berkredit dan tidak adanya perencanaan keuangan, apabila diaplikasikan ke dalam kehidupan keluarga , kesalahan pengelolaan keuangan seperti kesalahan membeli barang yang tidak diperlukan karena tidak adanya perencanaan keuangan terlebih dahulu, sehingga gaji bulanan habis sebelum waktunya. Pengetahuan keuangan adalah dasar faktor kritis dalam pengambilan keputusan keuangan(Kholilah et al., 2013). Namun pendapat berbeda dari hasil penelitian yang menyatakan bahwa literasi keuangan tidak berpengaruh terhadap perilaku keuangan Ibu rumah tangga di kota Tasikmalaya(Kusnandar et al :2018)

Pengalaman setiap keluarga dalam mengelola keuangan berbeda-beda seperti dalam perencanaan berinvestasi, menabung, dana pensiun, asuransi dan juga kredit. Dalam penelitian dari Purwidianti \& Mudiyanti (2016) bahwa pengalaman keuangan mempunyai pengaruh signifikan dengan perilaku keuangan Pengalaman sangat dibutuhkan dalam mengelola keuangan demi kelangsungan hidup dimasa akan datang. Pengalaman keluarga merupakan pembelajaran dalam mengelola keuangan sehingga dapat menangambil keputusan keuangan secara bijak, dimana semakin banyak pengalaman sesorangan maka akan semakin baik dalam mengambil keputusan keuangan.

Tujuan dari penelitian ini adalah untuk mengetahui seberapa besar pengaruh literasi keuangan dan pengalaman keuangan dalam membentuk perilaku keuangan pengguna aplikasi OVO pada ibu 
rumah tangga di Kecamatan Kedawung Cirebon

\section{KAJIAN TEORETIK Pengetahuan Keuangan}

Menurut Potrich et al., (2016) Pengetahuan keuangan memiliki 2 (dua) dimensi pendekatan, yaitu: pengetahuan keuangan dasar dan pengetahuan keuangan lanjutan. Pengetahuan keuangan dasar merupakan pengetahuan individu mengenai konsep dasar terkait dengan komposisi keuangan, meliputi: tarif pajak, inflasi, dan nilai uang berdasarkan waktu, sedangkan pengetahuan keuangan lanjutan merupakan pengetahuan individu mengenai instrumen- instrumen investasi, fungsi dari pasar modal, dan pemilihan investasi pada instrumen tertentu. Pengetahuan akan tingkat suku bunga, inflasi, dan resiko merupakan bentuk pengetahuan keuangan lanjutan yang harus dimiliki oleh individu dalam mengambil sebuah keputusan terkait dengan keuangannya.

Menurut Puspita et al (2019), pengetahuan keuangan didefinisikan sebagai pengetahuan individu mengenai situasi keuangan nya sendiri yang dihasilkan dari pemahaman konsep keuangan dan memperlakukannnya sebagai prasyarat untuk mengambil keputusan keuangan secara efektif. Kondisi ini menunjjukan bahwa pengetahuan keuangan individu tidak hanya terbatas pada pemahaman atas pendapatan dan pengeluaran yang terjadi, melainkan terdapat unsur keuangan lain yang dapat mempengaruhi keputusan individu dalam mengelola keuangannya .

Para ahli juga umumnya setuju bahwa pengetahuan keuangan tampaknya memiliki pengaruh langsung dengan perilaku keuangan agar dapat menguntungkan diri sendiri Hilgert et al., (2003). Menurut Kholilah et al., (2013) Kebanyakan orang mendambakan kehidupan yang sejahtera, yang berkualitas dan keamanan keuangan.

\section{Pengalaman Keuangan}

Pengalaman keuangan adalah kemampuan untuk membuat pertimbangan dari kejadian yang berbuhungan tentang masalah keuangan yang pernah dialami (dijalani, dirasakan, ditanggung dan sebagainya) baik yang sudah lama atau baru saja terjadi sehingga dari pengalaman keuangan tersebut dapat mendorong perilaku mengelola keuangan yang baik (Hogarth et al.,(2002); Silvy\&Yulianti :2013)

Lusardi \&Tufano (2015) menyatakan bahwa pengalaman keuangan yang baik adalah ketika seseorang memiliki pengetahuan yang lebih baik, karena akan melakukan pinjaman yang sesuai dengan kemampuan keuangan yang dimiliki sehingga mampu membayar tagihan dengan tepat waktu begitu pula sebaliknya. Pengalaman setiap individu dalam mengelola keuangan berbeda-beda, seperti dalam merencanakan investasi. Pengalaman individu Perilaku keuangan yang baik adalah kemampuan individu yang mampu mengakumulasi dan mengelola aset dengan baik ((Herd et al., 2012) Reviandiani (2019)menjelaskan bahwa pengalaman keuangan masing masing individu adalah penting untuk dipertimbangkan dan diambil keputusan berinvestasi. Dimana pengalaman itu mempengaruhi perhitungan pendapatan memiliki efek positif pada perilaku keuangan

\section{Perilaku Keuangan}

Bondt et al., (2008) menyatakan studi tentang bagaimana psikologi berdampak pada keputusan-keputusan keuangan di dalam rumah tangga, pasar dan organisasi. Perilaku keuangan (financial behavior) berhubungan dengan tanggung jawab keuangan seseorang terkait dengan cara pengelolaan keuangan. Pengelolaan keuangan merupakan cara mengelola uang yang diperoleh dan dinikmati untuk kehidupan saat ini sambil memperhatikan kehidupan di masa datang. Pengelolaan keuangan umum menyangkut tiga aspek utama, yaitu konsumsi, tabungan, dan investasi Purwidianti et al.,(2016) serta Wastam Wahyu Hidayat et al., (2021) dan (Hardiansyah et al., 2019). 
Seseorang yang memiliki perilaku keuangan yang bertanggung jawab cenderung efektif dalam penggunaan uang yang dimilikinya, seperti membuat anggaran, menghemat uang dan mengontrol belanja, investasi, serta membayar kewajiban tepat waktu (shalahuddinta\&Susanti: 2014)

Perilaku keuangan berhubungan dengan tanggung jawab keuangan seseorang terkait dengan cara pengelolaan keuangan. Tanggung jawab keuangan merupakan proses pengelolaan uang dan fase yang dilakukan secara produktif (Ida dan Dwinta, 2010). Menurut (Dew et al., 2011) financial behavior mencakup tiga dimensi keuangan, yaitu:

a. Consumption Konsumsi adalah pengeluaran atas berbagai barang dan jasa.

b. Cash-flow management Arus kas adalah indikator utama dari kesehatan keuangan yaitu ukuran kemampuan seseorang untuk membayar segala biaya yang dimilikinya, manajemen arus kas yang baik adalah tindakan penyeimbangan, masukan uang tunai dan pengeluaran.

c. Saving and Investment Tabungan dapat didefinisikan sebagai bagian dari pendapatan yang tidak dikonsumsi dalam periode tertentu

\section{Kerangka Penelitian}

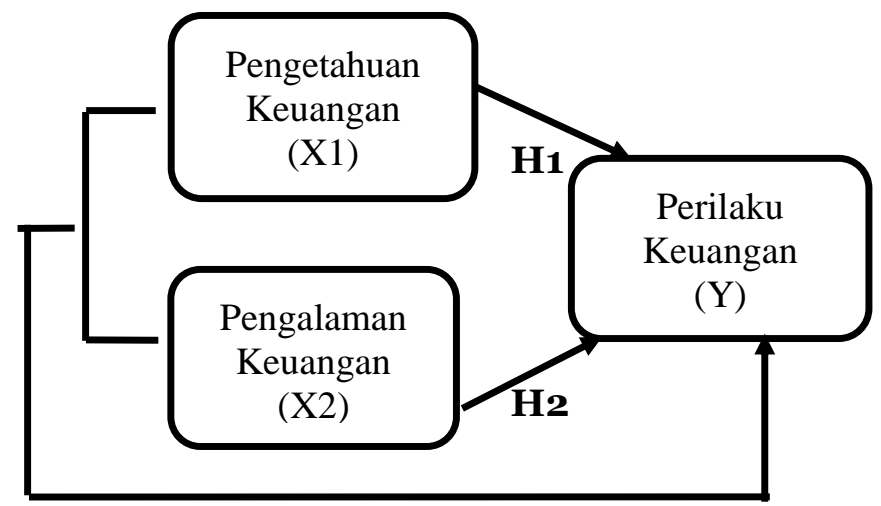

H3

\section{Hipotesis}

Seperti yang telah dikemukakan sebelumnya, hipotesis yang diajukan dalam penelitian ini adalah sebagai berikut :
H1 Pengetahuan
Keuangan
mempunyai pengaruh positif dan
signifikan terhadap perilaku
keuangan
H2 Pengalaman keuangan mempunyai terhadap perilaku keuangan pengaruh positif dan signifikan
H3 Pengetahuan Keuangan dan Pengalaman keuangan ber pengaruh positif dan signifikan secara bersamaan

\section{METODE PENELITIAN}

Jenis penelitian yang akan digunakan dalam penelitian ini adalah deskriptif kuantitatif yaitu data yang diperoleh dari sampel populasi penelitian dianalisis sesuai dengan metode statistik yang digunakan kemudian diinterprestasikan. Metode pengambilan sampel yang digunakan dalam penelitian ini adalah dengan metode non probability sampling, Adapun sampelnya adalah sebanyak 80 responden . Analisis data yang digunakan adalah dengan uji asumsi klasik, analisis regresi linear berganda, analisis korelasi,uji F (simultan) dan Determinasi.

\section{HASIL PENELITIAN DAN PEMBAHASAN}

\section{Karakteristik Responden}

Subjek dalam penelitian ini adalah keluarga di kecamatan Kedawung Kabupaten Cirebon sebanyak 80 orang 
Tabel 1. Karakteristik Responden

\begin{tabular}{llcc}
\hline Variabel & Klasifikasi & Jumlah & Persentase \\
\hline Usia & $>30$ & 69 & $86,3 \%$ \\
& $<30$ & 11 & $13,7 \%$ \\
Pendidkan & S2 & 14 & $17,5 \%$ \\
& S1 & 49 & $61,3 \%$ \\
& D III & 4 & $5 \%$ \\
& D I & 1 & $1,3 \%$ \\
& SMA & 12 & $15 \%$ \\
\hline
\end{tabular}

Sumber :Pengolahan data (2021)

Dari tabel 1 diatas dapat dilihat bahwa Jenjang pendidikan di dominasi oleh S1 dengan dapat ditarik kesimpulan bahwa Tingkat pendidikan sangat penting untuk mendukung pengetahuan keuangan dan pengalaman keuangan agar pelaku membentuk perilaku yang melek finansial. Konsep dan instrument keuangan untuk membuat keputusan keuangan yang tepat sangat tergantung pada tingkat pendidikan seseorang, hal ini sejalan dengan hasil penelitian dari Widayati( 2012)bahwa aspek kognitif dan aspek sikap memiliki hubungan antara pembelajaran di perguruan tinggi dengan tingkat literasi. tingkat pendidikan,

\section{Hasil Uji Normalitas}

Tabel 2 Hasil Uji Normalitas

\begin{tabular}{llr}
\hline \multicolumn{2}{c}{ One-Sample Kolmogorov-Smirnov Test } \\
& & $\begin{array}{r}\text { Unstandardized } \\
\text { Residual }\end{array}$ \\
& & 80 \\
$\mathrm{~N}$ & Mean & .0000000 \\
Normal & & \\
Parameters ${ }^{\mathrm{a}, \mathrm{b}}$ & Std. Deviation & .058 \\
& Absolute & .058 \\
Most Extreme & Positive & -.048 \\
Differences & Negative & .058 \\
& & $.2000^{\mathrm{c}, \mathrm{d}}$ \\
Test Statistic & & \\
$\begin{array}{l}\text { Asymp. Sig. (2- } \\
\text { tailed) }\end{array}$ & & \\
\hline Sumber: Pengolahan
\end{tabular}

Sumber: Pengolahan Data SPSS (2021)
Berdasarkan hasil tabel 2 uji normalitas diketahui signifikansi 0,200 > 0,005, maka disimpulkan bahwa nilai residual berdistribusi normal. Perbandingan antara probability dengan standar signifikansi yang sudah ditentukan diketahui bahwa nilai probability lebih besar dari 0,005.

\section{Hasil Uji Multikolinearitas}

Tabel 3 Uji Multikolinearitas

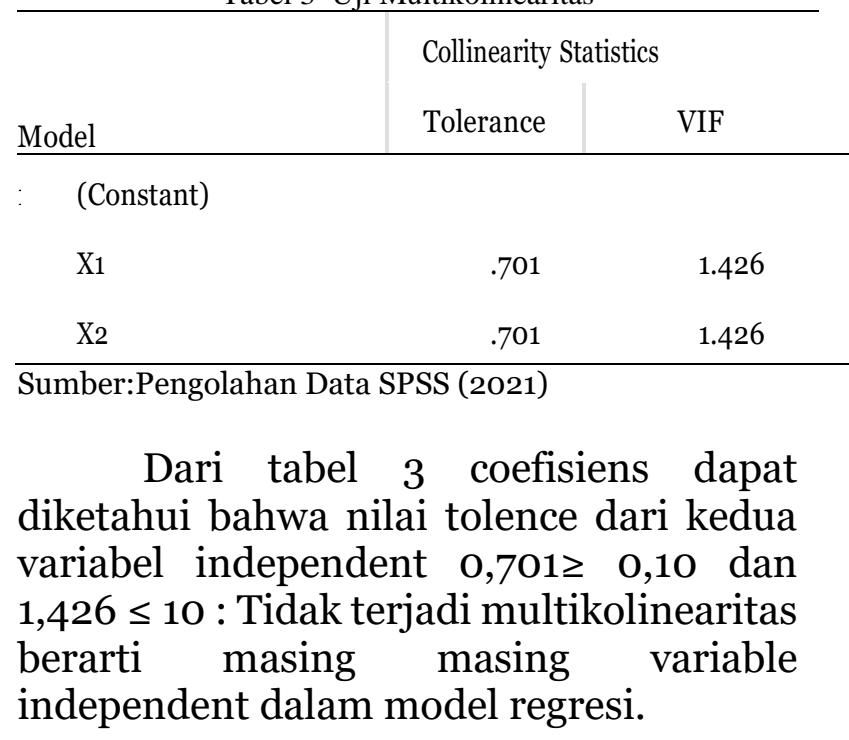

\section{Hasil Uji Heteroskedasitas}

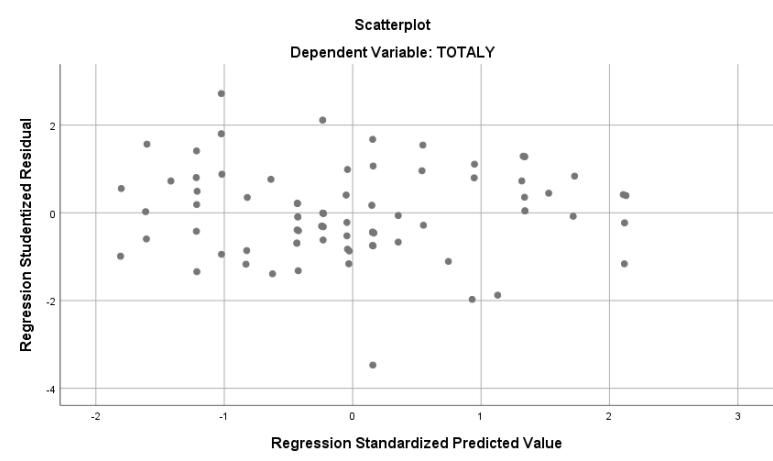

$$
\begin{gathered}
\text { Gambar 2. Heteroskedasitas } \\
\text { Sumber:Pengolahan Data SPSS (2021) }
\end{gathered}
$$

Dari gambar 2 hasil uji Heteroskedasitas di atas dapat diketahui bahwa tidak ada pola tertentu yang teratur 
pada grafik scatterplot serta titik-titik menyebar di atas dan di bawah angka o pada sumbu Y. Dengan demikian dapat dikatakan bahwa data dalam penelitian ini tidak terjadi heteroskedastisitas

\section{Hasil Pengujian Hipotesis}

\begin{tabular}{|c|c|c|c|c|}
\hline & $\begin{array}{l}\text { Unstandardi } \\
\text { zed } \\
\text { Coefficients }\end{array}$ & $\begin{array}{l}\text { Standardized } \\
\text { Coefficients }\end{array}$ & $\mathrm{t}$ & Sig. \\
\hline B & Std. Error & Beta & & \\
\hline (Constant) 6,675 & 1,295 & & 5,155 & 0 \\
\hline 0,154 & 0,044 & 0,367 & 3,512 & 0,001 \\
\hline 0,127 & 0,046 & 0,287 & 2,741 & 0,007 \\
\hline
\end{tabular}

Dari tabel 4 diatas dapat diketahui bahwa Pengujian yang dilakukan pada analisis regresi linear berganda, maka hasil persamaan regresi sebagai berikut:

$\mathrm{Y}=6,675+0,154 \mathrm{X} 1+0,127 \mathrm{X} 2$

Persamaan regresi diatas memperlihatkan hubungan antara variabel independent dengan variabel dependent secara parsial dan dari persamaan tersebut dapat diambil kesimpulan bahwa:

1. Nilai constanta adalah 6,675 artinya jika tidak terjadi perubahan variabel Pengetahuan keuangan (X1)dan pengalaman keuangan (X2 ) maka perilaku keuangan adalah sebesar 6,675 satuan.

2. Nilai koofesien regresi pengetahuan keuangan (X1) adalah o,154 artinya jika variabel pengetahuan keuangan (X1) meningkat sebesar 1\% dengan asumsi variabel pengalaman keuangan dan konstanta (a) adalah o (nol) maka kapasitas perilaku keuangan meningkat sebesar 15,4\%\%.hal tersebut menunjukan bahwa variabel pengetahuan keuangan yang disediakan berkontribusi positif bagi perilaku keuangan , sehingga makin baik pengetahuan keuangan maka semakin baik pula perilaku keuangannya

3. Nilai koefisien regresi pengalaman keuangan adalah 0,127 artinya jika variabel pengalaman keuangan (x2) meningkat sebesar 1\% dengan asumsi pengetahuan (x1) dan konstantan (a) adalah o (nol) maka perilaku keungan akan membaik

\section{Hasil Uji Hipotesis (Uji T )}

Tabel 5 Hasil Uji Hipotesis

\begin{tabular}{|c|c|c|c|c|c|c|}
\hline & \multicolumn{3}{|c|}{ Unstandardized Coefficients } & $\begin{array}{r}\text { Standardized } \\
\text { Coefficients }\end{array}$ & \multirow[t]{2}{*}{$\mathrm{t}$} & \multirow[t]{2}{*}{ Sig } \\
\hline & B & Std. & Error & Beta & & \\
\hline Constanta & 6,675 & 1,2 & & & 5,155 & 0 \\
\hline $\mathrm{X} 1$ & 0,154 & 0,0 & & 0,367 & 3,512 & 0,001 \\
\hline $\mathrm{X} 2$ & 0,127 & 0,0 & 46 & 0,287 & 2,741 & 0,007 \\
\hline
\end{tabular}

Berdasarkan hasil Uji Hipotesis pada tabel 5 dengan mengamati kolom $\mathrm{t}$ dan sig bisa dijelaskan sebagai berikut:

1.

2. Pengaruh variabel pengetahuan keuangan terhadap Perilaku Keuangan (H1)Variabel pengetahuan keuangan berpengaruh positif dan significan terhadap perilaku keuangan .hal ini terlihat Pengetahuan keuangan (X1)o,001 <0,05 dan nilai t tabel 1,99125 .berarti nilai t hitung lebih besar dari t tabel 3,512 >1,99125, maka Ho ditolak dan H1 diterima sehingga hipotesis yang berbunyi terdapat pengaruh pengetahuan keuangan tehadap perilaku keuangan secara parsial diterima. Pengaruh variabel pengalaman keuangan terhadap perilaku keuangan (H2) variabel pengalaman keuangan berpengaruh secara positif dan significan terhadap perilaku keuangan, hal ini terlihat daari (X2)0,007 < 0,05 nilai t tabel 1,99125. berarti 
nilai $\mathrm{t}$ hitung lebih besar dari $\mathrm{t}$ tabel 2,741>1,99125, maka Ho ditolak dan $\mathrm{H} 2$ diterima sehingga hipotesis yang berbunyi terdapat pengaruh pengalamanan keuangan

tehadap perilaku keuangan secara parsial diterima

\section{Hasil Uji Simultan F}

\begin{tabular}{ll|l|l|l|l}
\multicolumn{7}{c}{ Tabel 6 Hasil Uji F } & \\
\hline Sum of Squares & & df & $\begin{array}{l}\text { Mean } \\
\text { Square }\end{array}$ & F & Sig. \\
\hline Regression & 322,294 & 2 & 161,147 & 25,807 & , ooob \\
Residual & 605,706 & 97 & 6,244 & & \\
Total & 928 & 99 & & & \\
& & & & & \\
\hline
\end{tabular}

Sumber:Pengolahan Data SPSS (2021)

Berdasarkan hasil Uji F pada tabel 6 diatas bahwa diketahui pada nilai $F$ hitung $>$ F tabel atau 25,807 $>$ 3,11 dan tingkat significan adalah $0,000<0,05$ maka Ho ditolak dan $\mathrm{H}_{3}$ diterima dapat disimpulkan bahwa variabel pengetahuan keuangan (X1) dan Pengalaman keuangan (X2) secara bersaman berpengaruh significan terhadap perilaku keuangan

\section{Hasil Uji Determinan}

Tabel 7 Hasil Uji Determinan

\begin{tabular}{c|l|l|l}
\hline $\mathrm{R}$ & R Square & $\begin{array}{l}\text { djusted } \mathrm{R} \\
\text { Square }\end{array}$ & $\begin{array}{c}\text { Std. Errorof the } \\
\text { Estimate }\end{array}$ \\
\hline, $589^{\mathrm{a}}$ & 0,347 & 0,334 & 2,499 \\
\hline
\end{tabular}

Sumber:Pengolahan Data SPSS (2021)

Berdasarkan hasil uji Determinasi tabel 7 diatas dapat diketahui bahwa nilai koefisien determinan terdapat pada nilai adjusted $\mathrm{R}$ square sebesar 0,347 . Hal ini berarti kemampuan variabel bebas dalam menjelaskan variabel terikat adalah sebesar $34,7 \%$ sisanya dijelaskan oleh variabel lain $65,3 \%$

\section{Pengaruh Pengetahuan Keuangan Terhadap Perilaku Keuangan Ibu Rumah Tangga Pengguna OVO}

Hasil penelitian mendukung hipotesis pertama bahwa Variabel pengetahuan keuangan (X1) berpengaruh signifikan terhadap perilaku keuangan .hal ini terlihat Pengetahuan keuangan (X1)0,001 <0,05 dan nilai $t$ tabel 1,99125 .berarti nilai t hitung lebih besar dari t tabel 3,512 >1,99125, maka Ho ditolak dan H1 diterima sehingga hipotesis yang berbunyi terdapat pengaruh pengetahuan keuangan tehadap perilaku keuangan secara parsial diterima. Koefisien regresi pengetahuan keuangan (X1) sebesar 0,154 . dengan kata lain bahwa variabel pengetahuan keuangan mempunyai pengaruh yang positif terhadap perilaku keuangan . Ibu rumah tangga di kecamatan Kedawung Cirebon berdasarkan pemahaman Pengetahuan dasar, keyakinan dan memahami manfaat mengenai OVO sudah cukup baik .

Pernyataan hasil penelitian diatas sejalan dengan penelitian bahwa Pengetahuan keuangan berpengaruh positif terhadap perilaku keuangan (Ubaidillah et al,2019) Begitu pula dengan literasi keuangan, dan perencanaan keuangan berpengaruh positif dan signifikan terhadap perilaku keuangan . (Arianti, 2020)

\section{Pengaruh Pengalaman Keuangan Terhadap Perilaku Keuangan Ibu Rumah Tangga Pengguna OVO}

Hasil Penelitian mendukung hipotesis kedua bahwa Variabel pengalaman keuangan (X2) berpengaruh secara signifikan terhadap perilaku keuangan, hal ini terlihat daari (X2) 0,007 $<0,05$ nilai $t$ tabel 1,99125. berarti nilai $t$ hitung lebih besar dari $t$ tabel 
2,741>1,99125, maka Ho ditolak dan $\mathrm{H} 2$ diterima sehingga hipotesis yang berbunyi terdapat pengaruh pengalamanan keuangan tehadap perilaku keuangan secara parsial diterima. Nilai koefisien regresi pengalaman keuangan adalah o,127 artinya jika variabel pengalaman keuangan (x2) meningkat sebesar 1\% dengan asumsi pengetahuan (x1) dan konstantan (a) adalah o (nol) maka perilaku keungan akan membaik 12,7\%.dengan kata lain bahwa pengalaman keuangan berpengaruh positif terhadap perilaku keuangan.Perencanaan dalam menggunakan OVO para ibu di kecamatan sudah cukup baik

Hasil Penelitian ini Sejalan dengan penelitian dari (Purwidianti\&Darmawan :2019) menunjukan Financial experience mempengaruhi pengetahuan pengelolaan keuangan sehingga seseorang meningkatkan kemampuan dalam mengelola keuangan maka harus menambah pengalaman terkait keuangan. Hasil survey menyatakan bahwa responden di dominasi oleh umur lebih dari 30 tahun, kematangan usia akan berdampak pada pengalaman keuangan yang lebih banyak hal ini lah nantinya akan mempengaruh perilaku keuangan keluarga , hal ini sejalan dengan hasil penelitian ((Setiawan et al., 2016) sosial demografi dan sikap keuangan berpengaruh positif signifikan terhadap perilaku investasi keuangan individu.

\section{Pengaruh Pengetahuan Keuangan Dan Pengalaman Keuangan Terhadap Perilaku Keuangan}

Hasil penelitian mendukung hipotesis ke tiga yaitu Pada nilai F hitung $>$ F tabel atau 25,807 > 3,11 dan tingkat significan adalah $0,000<0,05$ maka Ho ditolak dan $\mathrm{H}_{3}$ diterima dapat disimpulkan bahwa variabel pengetahuan keuangan (X1) dan Pengalaman keuangan (X2) secara bersaman berpengaruh significan terhadap perilaku keuangan Berdasarkan tabel $\mathrm{R}$ square dapat diketahui bahwa nilai koefisien determinan terdapat pada nilai adjusted $\mathrm{R}$ square sebesar 0,347 .

Hal ini berarti kemampuan variabel bebas dalam menjelaskan variabel terikatadalah sebesar $34,7 \%$ sisanya dijelaskan oleh variabel lain 65,3\%

\section{KESIMPULAN}

1. Adanya pengaruh positif dan signifikan Pengetahuan keuangan pada perilaku keuangan keluarga Kecamatan Kedawung Kabupaten cirebon

2. Adanya pengaruh positif dan significan Pengalalman keuangan pada perilaku keuangan keluarga Kecamatan kedawung Kabupaten Cirebon

3. Pengetahuan keuangan dan pengalaman keuangan secara bersamaan berpengaruh significan dan positif

\section{SARAN}

Implikasi teoritis memberikan gambaran sebuah perbandingan mengenai rujukan- rujukan yang dipergunakan dalam penelitian ini. Perbandingan ini dapat ditunjukkan dari rujukan penelitian terdahulu dengan temuan penelitian saat ini. Implikasi teoritis ini dikembangkan untuk memperkuat dukungan atas beberapa penelitian terdahulu yang menjadi rujukan pada studi ini, dimana penelitian ini menunjukkan variabel yang digunakan yaitu pengetahuan keuangan,pengalaman keuangan dan perilaku keuangan. Hasil dari temuan penelitian dapat direkomendasikan beberapa implikasi kebijakan sesuai dengan prioritas yang dapat diberikan 
sebagai masukan bagi individu, praktisi, maupun penyedia jasa keuangan.

Adanya pembinaan dan pelatihan para ibu rumah tangga di kecamatan Kedawung terkait dengan keterampilan akan fitur dalam memahami pengetahuan keuangan terkait dengan aplikasi OVO .Pengalaman dalam mengelola keuangan dengan aplikasi OVO masih perlu ditingkatkan dan masih perlu beradaptasi . Diharapkan pada penelitian selanjutnya penulis dapat menambahkan variabel variabel lain yang berpengaruh pada perilaku keuangan misalkan variabel life style pada remaja. (usia sekolah SD-SMA)

\section{Daftar Pustaka}

Arianti, B. F. (2020). Pengaruh Pendapatan Dan Perilaku Keuangan Terhadap Literasi Keuangan Melalui Keputusan Berinvestasi Sebagai Variabel Intervening. Jurnal Akuntansi, $10(1), \quad 13-36 . \quad$ doi: 10.33369/J.Akuntansi.10.1.13-36

Bhushan, P., \& Medury, Y. (2014). Financial literacy and its determinants. https://www.researchgate.net/publicatio n/264355562

Bondt, W. de.,Muradoglu, Y., H,shefrin H,Staikouras (2008). Behavioral finance: Quo vadis? Journal of Applied Finance Vol 18 no.2

Dew, J., \& Xiao, J. (2011). The financial management behavior scale: Development and validation. Journal of financial Counselingf and Planning ,22(1),19-35

https://scholarsarchive.byu.edu/facpub/ $4521 /$

Hardiansyah, A., Soehardi, S., \& Rony, Z. T. (2019). PENGARUH DISIPLIN KERJA, MOTIVASI KERJA DAN KOMPENSASI TERHADAP KINERJA PEGAWAI BANK OCBC NISP BAGIAN RECORD MANAGEMENT DAN PARTNERSHIP OPERATION. Jurnal Ilmiah Manajemen
Ubhara, 1(2), 147-161. https://doi.org/http://dx.doi.org/10.3159 9/jmu.v1i2.644

Herd, P., Holden, K., \& Su, Y. T. (2012). The Links between Early-Life Cognition and Schooling and Late-Life Financial Knowledge. Journal of Consumer Affairs, 46(3), 411-435. doi: 10.1111/J.17456606.2012.01235.X

Herlinawati L.,Krisnawati A (2021)Pengaruh Literasi Keuangan Terhadap Keputusan Penggunaan Ovo Pada Ibu Rumah Tangga Di Kota Bandung. eProceeding of Management Vol 8,No.3

Hilgert, M., Hogarth, J., (2003) . Household Financial Management: The Connection Between Knowledge And Behavior. Hein Online .https://heinonline.org/hol-cgibin/get_pdf.cgi?handle=hein.journals/fe dred89\&section $=90$

Hogarth, J., Hilgert,M (2002) Financial knowledge, experience and learning preferences: Preliminary results from a new survey on financial literacy. Consumer Interest Annual,Proceedings of the American Council on Consumer Interests 2002 Annual Conference, March, 2002. vol 48 .

Ida, I.,Dwinta CY (2010). Pengaruh Locus Of Control, financial knowledge, income terhadap financial management behavior. Jurnaltsm.Id, 12(3), 131-144. http://jurnaltsm.id/index.php/JBA/articl e/view/202

Iprice .co.id(2020) E-Wallet Lokal Masih Mendominasi Q2 20192020.https://iprice.co.id/trend/insights/ top-e-wallet-di-indonesia-2020/

Kholilah, N. al, (2013). Studi financial management behavior pada masyarakat surabaya. Journal.Perbanas.Ac.Id, 3(1), 69-80.

http://journal.perbanas.ac.id/index.php/j $\mathrm{bb} /$ article/view/255

Kusnandar, D., Kurniawan D (2018). Literasi Keuangan Dan Gaya Hidup Ibu Rumah Tangga Dalam Membentuk Perilaku 
Keuangan Keluarga Di Kota Tasikmalaya. Jp.Feb.Unsoed.Ac.Id.

http://www.jp.feb.unsoed.ac.id/index.ph $\mathrm{p} / \mathrm{sca}-1 /$ article/view/1194

Shalahuddin;Alfin;Susanti (2014) Pengaruh Pendidikan Keuangan Di Keluarga, Pengalaman Bekerja Dan Pembelajaran Di Perguruan Tinggi Terhadap Literasi Keuangan. Junal Pendidikan Akuntansi (JPAK)

https://onesearch.id/Record/IOS1796.art icle-9134

Lusardi, A., Tufano,P (2015). Debt literacy, financial experiences, and overindebtedness. Journal of Pension Economics \& Finance, Volume 14, Special Issue 4: Household Finance, October 2015 , pp. $332-368$

DOI:https://doi.org/10.1O17/S147474721 5000232

Reviandani , W (2019) Pengaruh Pengalaman Keuangan dan Tingkat Pendapatan Terhadap Perilaku Keuangan Keluarga di Desa Yosowilangun Kecamatan Manyar Gresik. Journal.Umg.Ac.Id. Retrieved from

http://journal.umg.ac.id/index.php/man ajerial/article/view/862

Widyawati,I (2012). Faktor-faktor yang mempengaruhi literasi finansial mahasiswa fakultas ekonomi dan bisnis Universitas Brawijaya. EJournal.Unipma.Ac.Id, 1(1). http://ejournal.unipma.ac.id/index.php/assets/ar ticle/view/527

Potrich, A. C. G., Vieira, K. M., \& Mendes-DaSilva, W. (2016). Development of a financial literacy model for university students. Management Research Review, 39(3), 356-376. doi: 10.1108/MRR-062014-0143/FULL/HTML

Purwidianti, W., Darmawan ,A.,Melliana SB (2019) The Effect of Financial-Related Experience, Behavioral Intention, Spiritual Intelligence and Gender on Family Financial Behavior. Journal Economic and Business Volume 2 no.2
Desember 2019 http://journals.ums.ac.id/index.php/mije b

Purwidianti, W.,Mudjiyanti R(2016) Analisis Pengaruh Pengalaman Keuangan Dan Tingkat Pendapatan Terhadap Perilaku Keuangan Keluarga Di Kecamatan Purwokerto Timur. Jurnal BENEFIT $\begin{array}{llll}\text { Volume } & 1 & \text { no.2 } & \text { Desember. }\end{array}$ http://journals.ums.ac.id/index.php/ben efit/article/view/3257

Puspita, G., Isnalita ,I (2019) .Financial Literacy: Pengetahuan, Kepercayaan Diri dan Perilaku Keuangan Mahasiswa Akuntansi. Owner.Polgan.Ac.Id. vol 3 no.2 doi: 10.33395/owner.v3i2.147

Setiawan, E., Wahyudi, S., \& MAWARDI, W. (2016). Pengaruh Sosial Demografi, Pengetahuan Keuangan, Dan Sikap Keuangan Terhadap Perilaku Investasi Keuangan Individu (Studi Kasus Pada Karyawan Swasta Di kabupaten kudus). http://eprints.undip.ac.id/50508/

Silvy, M., Yulianti,N (2013). Sikap Pengelola Keuangan Dan Perilaku Perencanaan Investasi Keluarga Di Surabaya. Inkubator-Bisnis.Perbanas.Ac.Id, 3(1), 57-68. https://inkubatorbisnis.perbanas.ac.id/index.php/jbb/artic le/view/254

Ubaidillah, H., Haryono NA (2019) Pengaruh Demografi, Dan Literasi Keuangan Terhadap Perilaku Menabung Masyarakat Di Kabupaten Sidoarjo.Jurnal Ilmu Manajemen vol 7 No.1.

Usman,R(2017) Karakteristik Uang Elektronik Dalam Sistem Pembayaran. EJournal.Unair.Ac.Id. vol.32 no.1

Wastam Wahyu Hidayat, Soehardi, \& Husadha, C. (2021). Pengaruh Corporate Governance Terhadap Manajemen Pajak. Jurnal Manajemen Strategi Dan Aplikasi Bisnis, 4(2), 429-440. https://doi.org/http://www.ejournal.imp eriuminstitute.org/index.php/JMSAB/art icle/view/323 
51 | Perilaku Keuangan Ibu Rumah Tangga Pengguna E-Wallet Ovo di Kecamatan Kedawung Cirebon 